\title{
Snowy Owl Captures Duck
}

\author{
by Robert W. Nero, Regina
}

The numerous ducks which wintered this year on open water in the Regina Waterfowl Park (see Blue Jay, 22:20) attracted the attention of a number of Snowy Owls. On December 1, for example, Robert R. Taylor and I found four owls near the northeast section of the city harassing large flocks of Mallards which were feeding in the open stubble-fields. The appearance of a duck flock on the horizon nearly always elicited signs of interest from owls which we were watching at close range. On one occasion the behavior of an owl which was perched on top of a telephone pole drew our attention to a flock of ducks which were on the ground about a quarter of a mile away-the owl stood erect, stretched its neck, bobbed its head, and kept a fixed gaze in one direction. Finally it left its perch, flew rapidly, low, and straight toward the flock in the stubble; when it neared the flock it suddenly swooped upwards as if attempting to get above the birds, and at about the same time the ducks took flight. As far as we could tell the owl didn't even come close to any ducks, but had there been a cripple in the lot, or a slow-reacting individual, the owl would have been in a good position to attempt a kill. Similar harassing behavior in this general area, whic:h the ducks frequented for several weeks, was described to us by Ralph D. Carson; Dr. H. Albert Hochbaum has also observed this in the Delta Marsh area (personal communication).

We observed only attempted predation under these conditions. However on December 28, Doug and Dot Wade and I witnessed the successful pursuit arıd capture of a Lesser Scaup by a Sriowy Owl at the Regina Waterfowl Park. Early in the morning we found a fairly dark Snowy Owl perched on a pole at the south end of the Park. In mid-afternoon we visited "Goose Island," attempting to identify and count ducks as part of our Christmas week census. A moderate mist obscured our view of the ducks on the open water, but the day was bright and clear and our visibility otherwise was good. We saw a few ducks on the wing, one of which, a scaup, caught our attention by its rapid, direct flight along the course of the open water and then beyond, across the ice of the frozen channel. Just as the duck went out of our sight below the cover of adjacent land and vegetation, and while we were wondering what the duck was doing flying away from the water, we saw a Snowy Owl overhead. The owl was bearing directly on the course of the duck but it was several hundred yards behind it. It took us a few seconds to realize that the owl was in pursuit of the duck, but as it flew swiftly on with very rapid wing beats, dropping down toward where we had last seen the duck, its purpose became apparent. It covered this distance in less than a minute, dropped out of sight momentarily behind the same ridge, then rose abruptly, made a fast half-circle back on its route and pitched down out of our sight. We hurried across the island in order to get a view of the scene and shortly saw the owl sitting on an object out in the center of the frozen bay, beside the outlet pipes from the nearby power plant. We watched the owl plucking at its prey, then chased it off, hoping to retrieve the duck. The owl flew off with the duck in its feet, but it left behind the head of a female Lesser Scaup. Signs in the thin layer of snow on the ice convinced us that the duck had landed on the ice, and that the owl had seized it as it attempted to take flight. Diving ducks, of course, take flight with some difficulty and would be greatly handicapped in attempting to fly off a sheet of ice. It was presumably this disadvantage which enabled the owl to capture an apparently healthy duck. Why the duck chose to land on ice is a matter for conjecture; presumably it was aware that it was being pursued and it flew along the ice hoping to find open water, then landed when it encountered the outlet pipes which would be a considerable barrier to a bird flying low along the channel.

Snowy Owls doubtless take an occasional duck, but this would seem to be the exceptional case, restricted to situations where there are ducks wintering on open water; even here 
it seems likely that usually crippled individuals would be selected. The number of shot-crippled ducks is high, the number carrying lead shot but appearing to be healthy is even higher. Lloyd Keith states that "crippled ducks still surviving in open waterholes were constantly harassed" by wintering Snowy Owls (Keith, L. B. 1960. Observations on Snowy Owls at Delta, Manitoba. Can. Field Nat., 74: 106-112). Capture of free-flying ducks, as described above, must be rather unusual. At any rate, it seems reasonable to accept an oc- casional loss to an owl, meanwhile applauding their regular forays on the mouse populations. For us, that clear, cold day on Goose Island was a memorable event; the small duck speeding across the ice and out of sight, the owl in swift pursuit: these were the participants in a scene of breathtaking, fleet-winged skill and beauty. There was an inherent beauty, too, in the calm, deliberate way in which the owl sat and plucked at its prey-by these ancient patterns of behavior, energy is transferred from duck to owl.

\section{Recollection of An Encounter Between a Golden Eagle and a Great Blue Heron}

\section{by Dave Santy, Beechy}

On a sunny summer afternoon a few years ago while I was working in my garden two young lads, Alex Covey and Kenny Whidden, brought to me a large bird for identification. I readily recognized it as a Golden Eagle. The bird was in very bad condition and was gasping its last breath. The wet feathers that clung to the skin revealed that it was badly torn. The boys told me of having witnessed a fight between the eagle and a Great Blue Heron beside a pond formed by a dam across a coulee just north of the village of Beechy. The pond was a favourite watering and feeding place for many birds and other animals. Besides other forms of aquatic life it was heavily populated by salamanders which were a tidbit for the large wading heron, and no doubt also for the eagle. This was all well known to the boys who were wont to crawl up from the low side of the dam and peer through the trees to see the antics of the various daily visitors.

At this time it would seem that all the other denizens of the pond had taken fright and had fled from the fury of the battle. The struggle between the eagle and the heron had apparently been going on for some time before the boys came on the scene. Evidence indicated that it had started in the water at the edge of the pond where the soft earth was much scratched and marked. Now, in the final rounds, the struggling pair had moved back farther and onto the grass. As the boys described it to me, the heron was more or less on its side, while the eagle was sitting upright on its outspread tail, braced by its feet. The eagle made no use of its beak as a weapon but rather depended on its fairly long legs and taloned feet to ward off the rapierlike thrusts of the long and sharp bill of the heron. Repeatedly, the long, arched neck of the heron would whip out and fairly knock its adversary off balance as well as tearing its flesh. The boys watched in amazement but it was now noticeable to them that the heron was showing exhaustion. Following one thrust it failed to recoil its neck; the head trailed to the ground, ard at once the talons of the eagle closed on it. The fight over, the boys ran to the corner of the closely woven wire fence to get the help of post braces to climb over; by the time they got to the birds the heron was dead. Its opponent, the eagle, was also dead within a few minutes of their bringing it to me.

\section{ANNUAL MEETING}

The S.N.H.S. will hold its 1964 annual meeting in the Saskatchewan Museum of Natural History, on Octaber 17. Please plan to attend, to hear reports of officers and committees and to help plan future activities of the society. 